\title{
Hand Soap Bar Limbah Daun Galam (Melaleuca Cajuputi) Sebagai Produk Hand Wash di Kota Palangka Raya
}

\author{
Muh. Azhari ${ }^{1)}$, Rudy Yoga Lesmana ${ }^{2)}$, Siti Juhairiah ${ }^{3)}$ \\ ${ }^{1,2,3)}$ Universitas Muhammadiyah Palangkaraya \\ arymuh84@gmail.com
}

\begin{abstract}
ABSTRAK: Permasalahan lingkungan akibat pemanfaatan jasa lingkungan merupakan hal yang serius, baik ampak jangka pendek dan jangka panjang. Contoh permasalahan lingkungan yang dijadikan objek kajian pengabdian yaitu limbah daun galam yang dihasilkan dari pemanfaatan bagian utama tanaman yaitu berupa papan. Daun galam yang belum dimanfaatkan oleh masyarakat secara optimal akan menjadi masalah tersendiri bagi lingkungan. Limbah daun galam berpotensi menjadi produk yang ekonomis serta sebagai salah satu produk untuk meminimalisir aktivitas mikroorganisme karena bahan kandungan aktif di dalam limbah daun galam yaitu seperti alpha-Terpineol, alpha-Farnesena, Metileugenol dan Azulena. Kegiatan pengabdian dilakukan di Wilayah Kota Palangka Raya dan berkerjasama dengan Pimpinan Daerah Muhammadiyah (PDM) Kota Palangka Raya, lalu produk olahan yang dihasilkan berupa Hand Soap Bar dibagikan ke masyarakat.
\end{abstract}

Kata kunci: Hand Soap Bar, Limbah Daun Galam

ABSTRACT: Environmental problems from the use of environmental service are serious, both short- term and long-term impacts. Examples of environmental problems used as objects of pengabdian are galam leaf waste from the use of galam boards. Leaf of galam before use optimally with a community will be a problem for the environment. Waste leaf of galam has the potential to be an economical product as well as one of the product to minimize the activity of microorganisms because have the active ingredient is alpha-Terpineol, alpha-Farnesena, Metileugenol and Azulena. The activities of pengabdian took place in the city of palangkaraya. the collaboration activity with Pimpinan Daerah Muhammadiyah (PDM) city of palangkaraya.finally hand soap bar product distributed to the community.

Keywords: Hand Soap Bar, Waste Leaf of Galam

\section{PENDAHULUAN}

Lingkungan dan sumberdaya yang ada di dalamnya merupakkan satu kesatuann yang tidak dapat dipisahkan, kandungan sumberdaya tersebut menjadi identitas ciri khas suatu daerah, misalnya di Kalimantan Tengah dengan lingkungan Gambut memiliki salah satu sumberdaya seperti Tanaman Pohon Galam. Pohon galam merupakan sumberdaya yang dimanfaatkan oleh masyarakat dalam memenuhi kebutuhan hidup, terutama dalam bidang papan (perumahan). Permasalahan yang timbul dari aktivitas tersebut adalah tidak terpakainya bagian lain selain batang tanaman utama dan dapat dikatakan menimbulkan masalah bagi lingkungan, yaitu sering disebut dengan limbah. Biomassa yang tidak dimanfaatkan sebenarnya masih memiliki potensi jika dikelola dengan baik untuk dijadikan produk lainnya, misalnya limbah daun galam yang dapat dikelola menjadi minyak atsiri (metabolisme sekunder). Tujuan kegiatan pengabdian yaitu untuk memanfaatkan limbah daun galam dan kandungan metabolisme sekunder di dalamnya menjadi sebuah produk yang dapat digunakan dan dijangkau oleh masyarakat, 
yaitu berupa sabun atau Hand Soap Bar. Kandungan limbah daun galam terdiri dari alpha-Terpineol, alpha-Farnesena, Metileugenol, dan Azulena yang bermanfaat dibidang kesehatan dan, kosmetik, biofuel, anti jamur, serta di bidang kuliner (Andria Agusta, 2000). Potensi tersebut yang dimanfaatkan untuk menghasilkan produk berupa sabun cuci tangan padat dan diharapkan manfaatnya dapat dirasakan masyarakat dengan kondisi pandemi Covid-19.

\section{PERMASALAHAN}

Permasalahan dari pelaksanaan kegiatan pengabdian kepada masyarakat disebab kan karena melimpahnya jumlah biomassa limbah daun galam yang tidak termanfaatkan oleh masyarakat, biasanya bagian tanaman galam yang dimanfaatkan dalam skala besar berupa batang tanaman utama untuk dijadikan papan pembangunan rumah, jalan dan kegiatan konstruksi lainnya. Permasalahan tersebut yang melandasi penggunaan daun galam menjadi produk berupa sabun, dan digunakan di masa pandemi Covid-19 untuk meminimalisir aktivitas mikroorganisme patogen.

\section{METODE PELAKSANAAN}

Kegiatan pengabdian tentang "Hand Soap Bar Limbah Daun Galam sebagai produk Hand Wash di Kota Palangka Raya" dilaksanakan bulan Mei sampai dengan bulan Juli 2020. Mulai dari pengumpulan alat dan bahan serta izin administrasi. Pembuatan produk dari limbah daun galam menjadi hand soap bar karena kondisi lingkungan saat ini (Covid-19) dan potensi yang dimiliki oleh daerah seperti Kota Palangka Raya. Metode pembuatan hand soap bar yaitu dengan metode cold process metode cold process merupakan metode pencampuran minyak dengan alkali dilakukan saat temperatur keduanya berada pada suhu 32-35 derajat celcius, kemudian dilakukan pengadukan dan terjadi pengentalan, setelah itu dimasukkan ke dalam cetakan, setelah itu di cetak setelah 1 x 24 jam, dan menunggu proses reaksi penyabunan selama 2 sampai dengan 4 minggu. Metode yang digunakan selain itu berupa metode demontrasi, dan sosialisai produk kepada masyarakat.

\section{PELAKSANAAN}

Pelaksanaan kegiatan dilakukan di Kota Palangka Raya mulai dari bulan MeiJuli 2020. Pelaksanaan kegiatan di lakukan di lapangan dan laboratorium. Misalnya kegiatan pengumpulan biomassa dilakukan di lapangan, kegiatan pembuatan sabun di lakukann di laboratorium MIPA Universitas Muhammadiyah Palangkaraya, lalu pembagian produk dilakukan di Kota Palangkaraya kerjasama dengan Pimpinan Daerah Muhammadiyah (DPM) Kota Palangka Raya. 


\section{HASIL DAN LUARAN}

Hasil yang diperoleh dari kegiatan pembuuatan Hand Soap Bar Limbah Daun Galam sebagai produk Hand Wash di Kota Palangka Raya yaitu berupa sabun batangan sebanyak 700 bar, dan dibagikan kepada masyarakat serta diberikan kepada Pimpinan Daerah Muhammadiyah Kota Palangka Raya (DPM) sebanyak 200 bar untuk dibagikan kepada masyarakat.

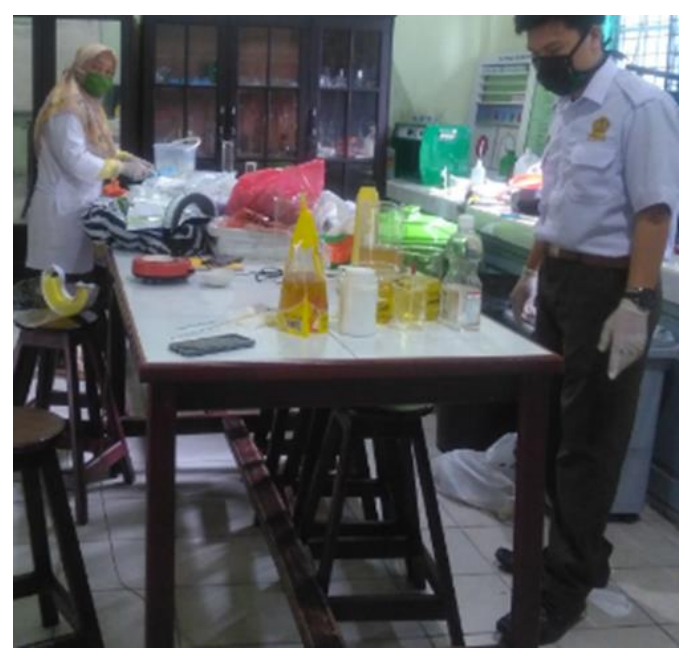

Gambar 1. Proses Pembuatan Sabun

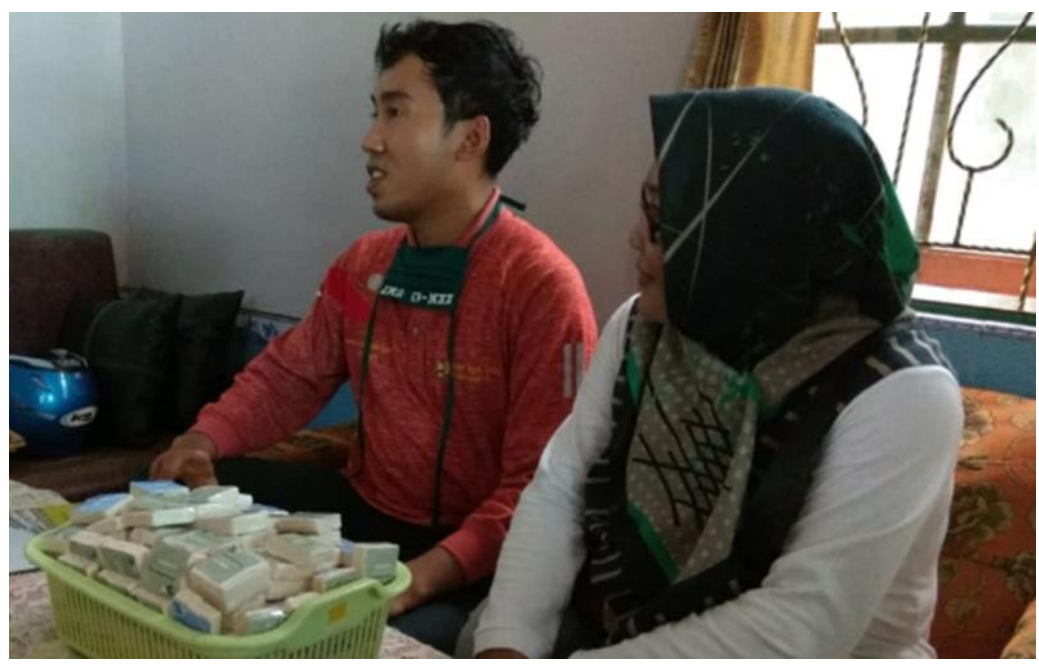

\section{Gambar 2. Kegiatan Serah Terima dengan PDM Kota Palangka Raya}

Pembuatan sabun batang terdiri dari minyak nabati, hidrosol limbah daun galam, $\mathrm{NaOH}$. Pembuatan sabun dengan teknik cold process dan mengacu kepada Metode saponifikasi. Metode tersebut digunakan agar produk sabun yang digunakan aman digunakan olehmasyarakat untuk dijadikan sabun cuci tangan dan berfungsi untuk meminimalisir aktivitas mikroorganisme (mikroorganisme patogen seperti Corona 
virus). Respon masyarakat yang diberikan produk berupa sabun merasa sangat terbantu, apalagi limbah daun galam sendiri memiliki kandungan aktif seperti alpha-Terpineol, alpha-Farnesena, Metileugenol, dan Azulena.

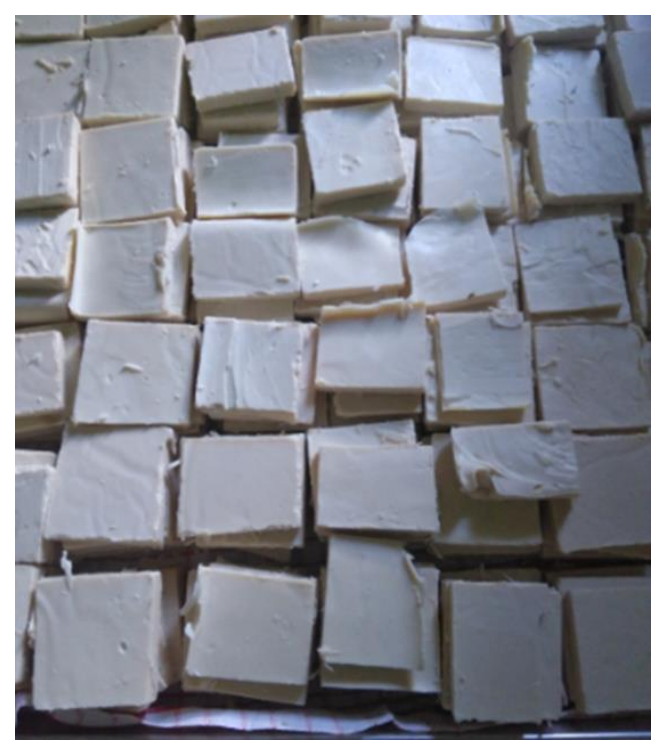

Gambar 3. Sabun dan proses sabunisasi

Fungsi bahan aktif tersebut dapat dijadikan sebagai bahan anti jamur, anti serangga, desinfektan, anti kanker, biofuel, parfum, penyedap, bidang farmasi, anti imflamasi, anti peradangan dan lain-lain.

\section{KESIMPULAN}

Kegiatan pengabdian yang dilakuakan terkait dengan pembuatan Hand soap bar dari limbah daun galam sebagai Hand wash memiliki peluang tersendiri yaitu sebagai alternatif penggunaan sabun cuci tangan di era Covid-19.

\section{DAFTAR PUSTAKA}

Agusta, A. 2000. Minyak Atsiri Tumbuhan Tropika Indonesia. ITB Press: Bandung. Rumbang, A. 2007. Pemantapan kawasan Hutan di Provinsi Kalimantan Tengah. Palangkaraya: Provinsi Kalimantan Tengah

Zulkifli, A. 2014. Dasar-dasar Ilmu Lingkungan. Saleba Teknik: Jakarta

Basuki. 2012. Penggunaan Kawasan Hutan untuk Budidaya non Kehutanan. Direktorat Perencanaan Hutan Ditjen Planologi Kehutanan Kementerian Kehutanan: Jakarta. Undang-Undang Republik Indonesia. 2009. Tentang Perlindungan dan Pengelolaan Lingkungan Hidup No. 32. Kementerian Lingkungan Hidup. 